\title{
THE PREVENTION OF ACTH-INDUCED SODIUM RETENTION BY THE USE OF POTASSIUM SALTS: A QUANTITATIVE STUDY
}

\author{
By GRANT W. LIDDLE,1 LESLIE L. BENNETT, AND PETER H. FORSHAM
}

(From the Metabolic Unit for Research in Arthritis and Allied Diseases, and the Departments of Medicine and Physiology, University of California School of Medicine, San

Francisco and Berkeley, Calif.)

(Submitted for publication June 4, 1953 ; accepted August 3, 1953)

Administration of large doses of either corticotropin (ACTH) (1) or the adrenal steroids (2-5) to human subjects ordinarily results in an initial phase of sodium retention which is often accompanied by increased excretion of potassium in the urine and by a decrease in intracellular potassium (6). In order to minimize potassium depletion, it has become common practice to add supplements of potassium salts to the diets of patients receiving large doses of ACTH or cortisone. The use of such supplements was also found to be extremely effective in overcoming the sodium retention induced by ACTH and by cortisone (7). The present study was designed to clarify the mechanism of the sodium diuresis which follows the ingestion of large amounts of potassium salts.

\section{SUBJECTS AND METHODS}

Thirty experiments were carried out in 14 subjects. Seven subjects were men, seven woman. Seven subjects had rheumatoid arthritis, one disseminated lupus erythematosus, one dermatomyositis, one gout, one multiple sclerosis, one hyperinsulinism, one Cushing's syndrome, and one no demonstrable disease. No subject with evidence of disease of the liver, kidneys, or of the pituitary or adrenal glands was included in this series.

Throughout the course of the study each subject was maintained on a constant diet. Total urinary output was collected. When appropriate, specimens of feces, saliva, and blood were taken for electrolyte determination. In most experiments, potassium salts were administered orally in small divided doses; in a few cases, the potassium salt was given by continuous intravenous infusion. ACTH was administered intramuscularly, either in aqueous solution every six hours or in 16 per cent gelatin every 24 hours. When either cortisone acetate or hydrocortisone was used, the daily dose was divided into four equal parts administered orally every six hours.

1 U. S. Public Health Service, Post-doctorate Fellow in Arthritis and Metabolic Diseases.

Present address: The Clinical Center, National Heart Institute, Bethesda 14, Md.
The following laboratory methods were employed: Sodium and potassium determinations were made, using a flame photometer (Perkin-Elmer Model 52-A) with lithium as an internal standard. Chloride was determined by the method of Schales and Asper $(8,9)$. Inorganic phosphorus was determined by the method of Fiske and Subbarow (10). Urinary ammonia was determined by the method of Folin and Bell (11). Urinary $\mathrm{pH}$ was estimated on freshly voided specimens by means of nitrazine paper. Urinary titratable acidity ${ }^{2}$ was determined by an adaptation of the method of Henderson and Palmer (12). In preparation for carbon dioxide-plus-bicarbonate determinations, urine was collected under oil in small amounts of carbon dioxide-poor sodium hydroxide solution; carbon dioxide-plus-bicarbonate was then determined on a Van Slyke and Neill manometric blood gas apparatus. Urine specimens for all other chemical determinations were collected in chemically clean glassware containing a known excess of sulfuric acid.

\section{RESULTS}

Representative results obtained in each category of experiments are as follows :

The regularity with which administration of ACTH results in retention of sodium in human subjects is illustrated in Figure 1. Subject A. A. received five courses of treatment, each employing a different preparation of ACTH. Retention of sodium occurred during administration of each preparation. Sodium excretion tended to return to control levels after the initial three or four days of treatment, but a frankly negative sodium balance was never observed as long as effective dosage of ACTH was maintained. The abrupt withdrawal of each preparation was followed by a marked diuresis of sodium. In our experience this pattern of sodium retention occurs invariably

\footnotetext{
2 The term "titratable acidity" as employed in this report actually refers to "titratable acidity minus carbon dioxide," inasmuch as carbon dioxide was driven off by "boiling" the urine under reduced pressure before titrating to $\mathrm{a} \mathrm{pH}$ of 7.4 .
} 


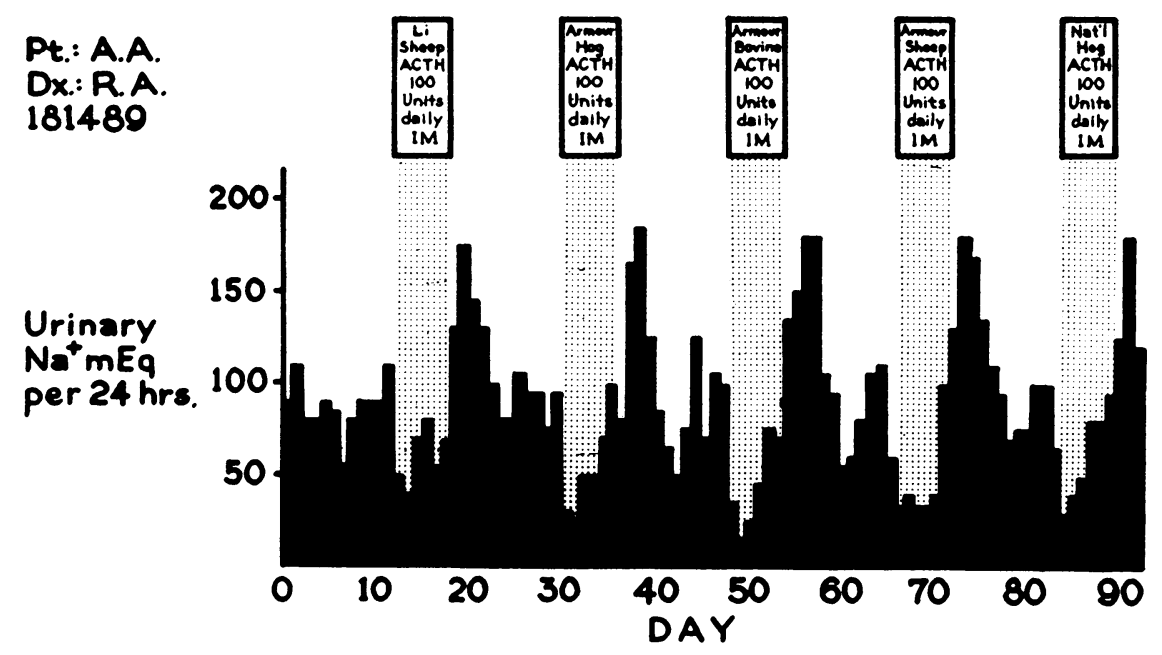

Fig. 1. Urinary Sodium as Influenced by Administration and Withdrawal of Five Different Preparations of ACth in Subject A. A. While Receiving a Constant Diet

in subjects with normal adrenals during continuous treatment with ACTH. The pattern may be profoundly modified, however, when potassium therapy is superimposed upon ACTH therapy.

Typically, the administration of potassium acetate results in sodium diuresis for approximately two days. Sodium excretion then returns to control levels, and there may even be a phase of sodium retention despite continued administration of the potassium salt. The sodium retention produced by $\mathrm{ACTH}$ can be completely prevented by simultaneous administration of large doses of potassium acetate (Figure 2). Subject L. G., after a control period of six days, was given potassium acetate, $360 \mathrm{mEq}$. daily, for a period of 12 days. This particular experiment was atypical in that only a minimal sodium diuresis occurred during the first two days of potassium administration. When ACTH was started on the seventh day of potassium administration, there was no evidence whatever of sodium retention. That potassium acetate had actually prevented the sodium-retaining effect of ACTH became apparent on the nineteenth day of the study, when the potassium salt was withdrawn. At this time the unopposed influence of ACTH became manifest, and the subject entered a phase of marked sodium retention. Finally, on the twenty-fifth day of the study, ACTH was withdrawn and a marked diuresis of sodium ensued.

The complete reversal of ACTH-induced so- dium retention by the administration of potassium acetate is illustrated in Figure 3. Subject R. D., after an initial control period, was treated with 25 international units of $\mathrm{ACTH}$, injected intramuscularly every six hours, and the expected phase of sodium retention was readily apparent. On the seventh day of ACTH therapy, the administration of potassium acetate was begun, and despite the fact that $\mathrm{ACTH}$ was continued, a striking sodium diuresis occurred, which resulted in a loss of more sodium than had been retained previously. It will be noted that the natriuretic effect of potassium acetate was maximal for only two days and disappeared after four days. After ACTH was withdrawn on the nineteenth day of the study, the sodium loss which usually follows sudden withdrawal of this hormone was hardly preceptible. Finally, on the twenty-fifth day of the study, potassium acetate was withdrawn, and a phase of almost complete sodium retention ensued. A reactive rebound phenomenon is well illustrated in this study: First, the sodium loss which occurred when potassium was administered was greater in magnitude than the preceding ACTH-induced sodium retention; second, the sodium retention which followed withdrawal of potassium exceeded in magnitude the sodium loss which occurred when potassium was administered.

Data presented in Figure 4 show that potassium acetate will also induce sodium diuresis in subjects not receiving ACTH. Subject A. A., who had 
PREVENTION OF ACTH-INDUCED Na+ RETENTION BY PROPHYLACTIC ADMINISTRATION OF $K^{\star}$

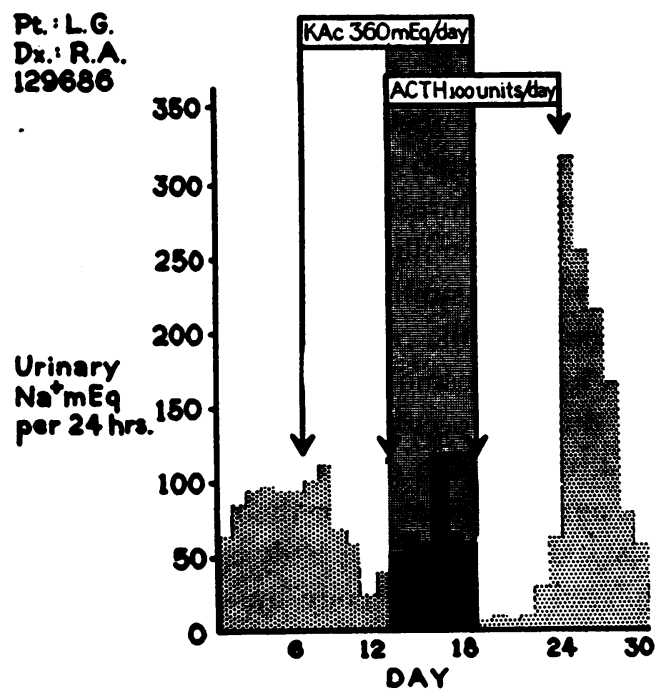

Fig. 2. Urinary Sodium as Influenced by Potassium Acetate and aCTH, Administered Separately and Smultaneously to Subject L. G. While Recerving a Constant Diet

not been treated previously with $\mathrm{ACTH}$, showed a moderate loss of sodium when he received 360 $\mathrm{mEq}$. of potassium acetate in one day. On the following days, sodium was retained. Subsequently, this subject was given the same amount of potassium acetate plus 100 units of ACTH for one day, and a similar sodium diuresis occurred. This indicates that the natriuretic effect of potassium acetate is not limited to subjects receiving corticotherapy.

It will be noted, however, that the sodium diuresis in subject A. A. was much less in magnitude than that observed in other subjects given potassium acetate in comparable doses, most likely because this subject, not having received ACTH, had not retained an excess of sodium before the potassium was administered. As shown in Figure 5 , it appears that the degree of sodium loss which occurs when potassium acetate is given is proportional to the body stores of sodium. For 17 days, subject $\mathrm{N}$. C. was given a diet in which sodium intake was severely restricted $(6 \mathrm{mEq}$. per day). During the first six days, urinary excretion of sodium gradually came into equilibrium with sodium intake. Administration of ACTH from the seventh day on resulted in little or no sodium retention. When potassium acetate $(360 \mathrm{mEq}$. per day) was added to the ACTH regimen from the eleventh through the fourteenth days, there was a slight but definite loss of sodium. Withdrawal of potassium was followed by a return to sodium equilibrium. Thus, administration of potassium acetate induces a negative sodium balance, even when not preceded by a phase of sodium retention; the sodium diuresis, however, is less intense when there has not been a preceding phase of sodium retention.

A number of theoretically possible mechanisms were tested in an effort to explain the natriuretic action of potassium salts. Is the natriuretic action a function of the potassium ion alone, or is it influenced by the type of anion administered with the potassium? The fact that potassium salts other than potassium acetate are also effective in producing sodium diuresis is illustrated by the experiments outlined in Tables I, II, and III. Subject V. N. (Table I) had been given intramuscular injections of highly purified ACTH gel, 40 international units daily, for a month by the time this study was begun and had presumably already passed through the early sodium-retaining phase. When

\section{REVERSAL OF ACTH-INDUCED Na' RETENTION BY ADMINISTRATION OF $K^{*}$}

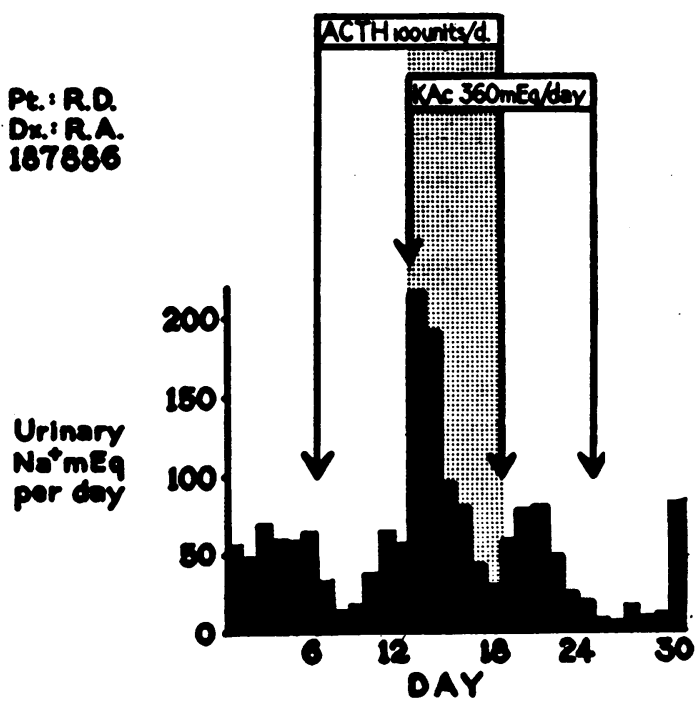

Fig. 3. Urinary Sodium as Influenced by ACTH and Potassium Acetate Administered Separately and Simultaneously to Subject R. D. While on a ConSTANT DIET 
$\mathrm{Na}^{+}$LOSS INDUCED BY $\mathrm{K}^{+}$ALONE
AND BY $\mathrm{K}^{+}$PLUS ACTH

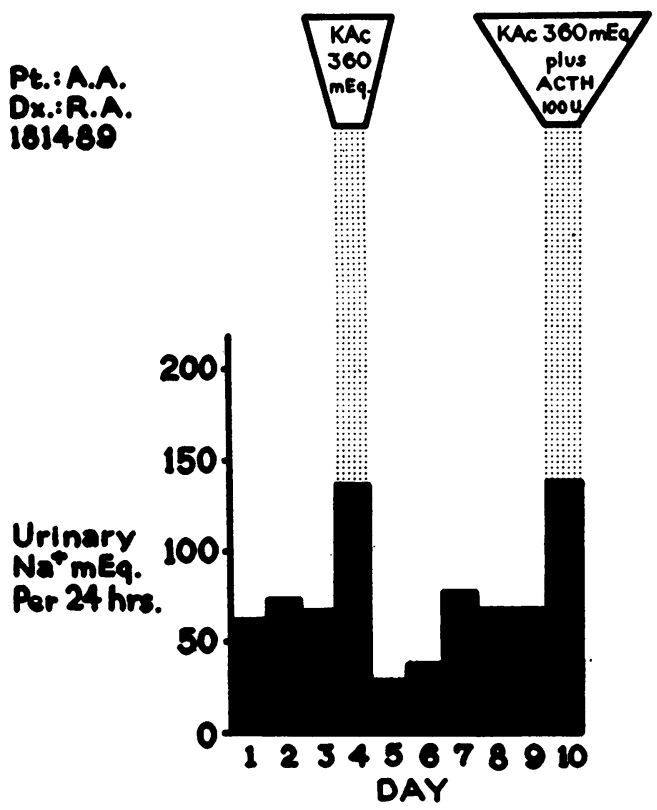

Fig. 4. Urinary Sodium as Influenced by Potassium Acetate Administered Alone and in Conjunction with ACTH without a Preceding Phase of ACTH-Induced Sodium Retention (Subject A. A.)

potassium chloride, $360 \mathrm{mEq}$. per day, was administered for six days, a very large loss of sodium occurred. Withdrawal of potassium chloride again permitted sodium retention.

As shown in Table II, the natriuretic effect of neutral potassium phosphate $(\mathrm{pH} 7.0)$ may not be obvious when the salt is administered orally, perhaps because phosphate given orally in such large doses causes diarrhea. But natriuresis is readily apparent when the potassium phosphate is given parenterally. In subject $N$. C., the continuous intravenous infusion of $360 \mathrm{mEq}$. of potassium in this form for a period of 15 hours resulted in a definite increase in urinary sodium. Similarly, as shown in Table $\mathrm{V}$, the intravenous administration of $180 \mathrm{mEq}$. of potassium phosphate $(\mathrm{pH} 7.5)$ to a patient with hypokalemia due to Cushing's syndrome resulted in a striking sodium diuresis even though the serum potassium never reached normal levels.

Inasmuch as potassium acetate, potassium chloride, and potassium phosphate are all natriuretic agents, it appears that an excess of the potassium ion per se may specifically induce sodium excretion.

Is the sodium loss based upon an "osmotic diuresis"? Subject R. Do. (Table III), while receiving no corticotherapy, was given 720 milliosmols of potassium chloride in one day, and a definite sodium diuresis occurred. One week later he was given 720 milli-osmols of potassium acetate in one day, and a similar sodium diuresis occurred. Subsequently, while on the same regimen, he was given 1440 milli-osmols of urea in one day, and no sodium diuresis occurred. It is apparent, therefore, that the sodium diuretic efficacy of potassium salts is not dependent upon their osmotic activity.

Does sodium leave the body simply because it is displaced within the body by an alternative cation, potassium? Figure 6 presents a comparison of sodium and potassium balances during a typical experiment. During the initial control period, the subject (R. D.) was in approximate sodium and potassium equilibrium. Administration of ACTH resulted in a decrease in urinary excretion of so-

\section{EFFECTS OF ACTH AND OF POTASSIUM UPON URINARY $\mathrm{Na}^{+}$ DURING RESTRICTION OF $\mathrm{Na}^{+}$INTAKE}

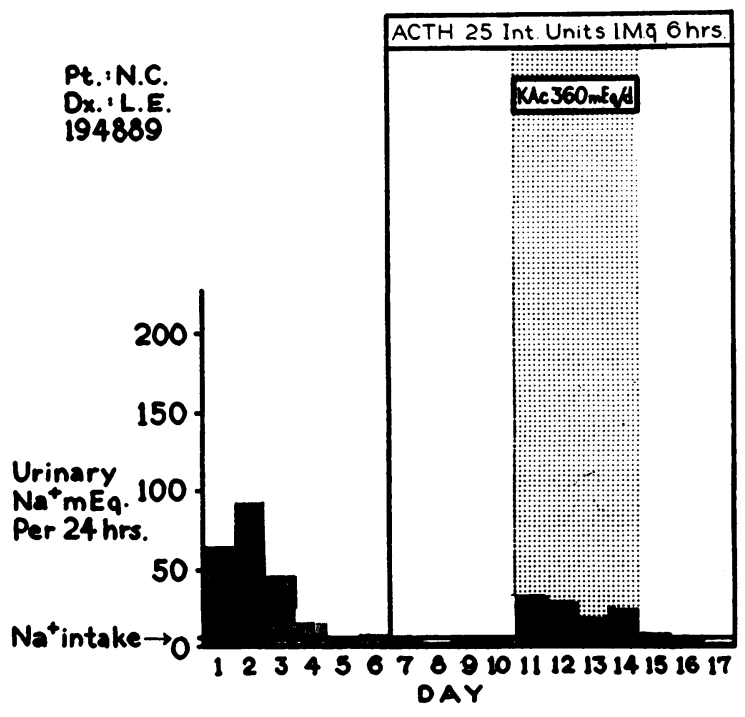

Fig. 5. Urinary Sodium as Influenced by ACTH and Potassium Acetate in Subject N. C. While on a Diet Containing $6 \mathrm{mEQ}$. of Sodium in an Attempt to Preclude Sodium Retention during ACTH AdminisTRATION 
TABLE I

The effects of potassium chloride on urinary electrolytes

Pt. V. N., No. 199815. White, female, 36 years. Dermatomyositis

\begin{tabular}{|c|c|c|c|c|c|c|c|c|c|c|c|c|c|c|}
\hline \multirow[b]{2}{*}{ Day } & \multirow{2}{*}{\multicolumn{2}{|c|}{$\begin{array}{r}\text { Treatment } \\
\end{array}$}} & \multicolumn{6}{|c|}{ 24-Hour urinary } & \multicolumn{4}{|c|}{ Serum } & \multicolumn{2}{|c|}{ Salivary } \\
\hline & & & $\underset{(m E q .)}{\mathrm{Na}}$ & $\underset{(m E q .)}{\mathrm{K}}$ & $\underset{(m E q .)}{\mathrm{Cl}}$ & $\underset{(m M)}{\mathrm{P}}$ & $\begin{array}{c}\text { Titr. } \\
\text { ac. } \\
(m E q .)\end{array}$ & $\underset{(m M)}{\mathrm{NH}_{3}}$ & $\begin{array}{c}\mathrm{Na} \\
\mathrm{mEq} / \mathrm{I} \\
L .\end{array}$ & $\underset{\substack{\mathrm{K} \\
\mathrm{Eq} .}}{\mathrm{K}}$ & 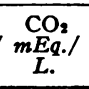 & $\underset{\substack{\mathrm{Cl} \\
\mathrm{El} q . /}}{L .}$ & $\begin{array}{c}\mathrm{Na} \\
m E q . / \\
L .\end{array}$ & $\underset{\substack{\mathrm{K} \\
\mathrm{Kq} .}}{\mathrm{K}}$ \\
\hline $\begin{array}{l}1-30 \\
31\end{array}$ & $\begin{array}{l}\text { ACTH daily } \\
\text { ACTH-gel } 40 \text { Int. } \\
\text { Units i.m. daily }\end{array}$ & & 74 & 115 & 95 & 30 & 27 & 83 & & & & & & \\
\hline 32 & $\begin{array}{l}\text { ACTH-gel } 40 \text { Int. } \\
\text { Units i.m. daily }\end{array}$ & & 66 & 110 & 86 & 29 & 22 & 92 & & & & & & \\
\hline 33 & $\begin{array}{l}\text { UCTH-gel } 40 \text { Int. } \\
\text { Units i.m. daily }\end{array}$ & & 76 & 108 & 90 & 30 & 26 & 82 & & & & & & \\
\hline 34 & $\begin{array}{l}\text { ACTH-gel } 40 \text { Int. } \\
\text { Units i.m. daily }\end{array}$ & & 75 & 102 & 95 & 31 & 33 & 83 & & & & & & \\
\hline 35 & $\begin{array}{l}\text { ACTH-gel } 40 \text { Int. } \\
\text { Units i.m. daily }\end{array}$ & & 73 & 123 & 95 & 27 & 24 & 96 & & & & & & \\
\hline 36 & $\begin{array}{l}\text { ACTH-gel } 40 \text { Int. } \\
\text { Units i.m. daily }\end{array}$ & & 82 & 108 & 107 & 30 & 0 & 80 & 138 & 2.7 & 36 & 95 & 7 & 29 \\
\hline 37 & $\begin{array}{l}\text { ACTH-gel } 40 \text { Int. } \\
\text { Units i.m. daily }\end{array}$ & $\begin{array}{l}\mathrm{KCl}, 27 \mathrm{Gm} . \\
\text { orally, daily }\end{array}$ & 228 & 306 & 296 & 18 & -128 & 13 & & & & & & \\
\hline 38 & $\begin{array}{l}\text { ACTH-gel } 40 \text { Int. } \\
\text { Units i.m. daily }\end{array}$ & $\begin{array}{l}\mathrm{KCl}, 27 \mathrm{Gm} . \\
\text { orally, daily }\end{array}$ & 220 & 436 & 481 & 24 & -33 & 25 & & & & & 7 & 30 \\
\hline 39 & $\begin{array}{l}\text { ACTH-gel } 40 \text { Int. } \\
\text { Units i.m. daily }\end{array}$ & $\begin{array}{l}\mathrm{KCl}, 27 \mathrm{Gm} \text {. } \\
\text { orally, daily }\end{array}$ & 126 & 461 & 407 & 25 & 11 & 30 & 140 & 4.4 & 28 & 106 & & \\
\hline 40 & $\begin{array}{l}\text { ACTH-gel } 40 \text { Int. } \\
\text { Units i.m. daily }\end{array}$ & $\begin{array}{l}\mathrm{KCl}, 27 \mathrm{Gm} \text {. } \\
\text { orally, daily }\end{array}$ & 66 & 457 & 418 & 27 & 31 & 34 & & & & & & \\
\hline 41 & $\begin{array}{l}\text { ACTH-gel } 40 \text { Int. } \\
\text { Units i.m. daily }\end{array}$ & $\begin{array}{l}\mathrm{KCl}, 27 \mathrm{Gm} \text {. } \\
\text { orally, daily }\end{array}$ & 152 & 432 & 482 & 25 & 26 & 25 & & & & & & \\
\hline 42 & $\begin{array}{l}\text { ACTH-gel } 40 \text { Int. } \\
\text { Units i.m. daily }\end{array}$ & $\begin{array}{l}\mathrm{KCl}, 27 \mathrm{Gm} \text {. } \\
\text { orally, daily }\end{array}$ & 120 & 444 & 455 & 25 & 20 & 21 & 142 & 4.8 & 27 & 101 & 6 & 29 \\
\hline 43 & $\begin{array}{l}\text { ACTH-gel } 40 \text { Int. } \\
\text { Units i.m. daily }\end{array}$ & & 42 & 187 & 181 & 31 & 50 & 32 & & & & & & \\
\hline 44 & $\begin{array}{l}\text { ACTH-gel } 40 \text { Int. } \\
\text { Units i.m. daily }\end{array}$ & & 21 & 75 & 49 & 24 & 40 & 58 & 139 & 3.4 & 31 & 94 & 5 & 28 \\
\hline 45 & $\begin{array}{l}\text { ACTH-gel } 40 \text { Int. } \\
\text { Units i.m. daily }\end{array}$ & & 42 & 98 & 105 & 25 & 35 & 81 & & & & & & \\
\hline 46 & $\begin{array}{l}\text { ACTH-gel } 40 \text { Int. } \\
\text { Units i.m. daily }\end{array}$ & & 72 & 99 & 105 & 24 & 26 & 84 & 143 & 3.1 & 30 & 94 & & \\
\hline 47 & $\begin{array}{l}\text { ACTH-gel } 40 \text { Int. } \\
\text { Units i.m. daily }\end{array}$ & & 82 & 109 & 100 & 26 & 25 & 96 & & & & & & \\
\hline 48 & $\begin{array}{l}\text { ACTH-gel } 40 \text { Int. } \\
\text { Units i.m. daily }\end{array}$ & & 74 & 98 & 95 & 28 & 20 & 80 & 140 & 3.1 & 35 & 96 & 6 & 32 \\
\hline
\end{tabular}

dium and a positive sodium balance, whereas the over-all potassium balance did not change. When large amounts of potassium acetate were administered, there was an initial phase of potassium retention concurrent with a striking loss of sodium. However, during this initial phase the absolute magnitude of the sodium loss was much greater than the magnitude of the potassium retention. Thus, the sodium loss could only be partially explained in terms of its displacement by potassium. It will be noted also that following the withdrawal of potassium acetate, the sodium retention was far greater in magnitude than the simultaneous potassium loss. This indicates that the administration or withdrawal of potassium influences the excretion of sodium to an extent which exceeds the direct exchange of one cation for the other.

Does potassium cause an increase in sodium excretion by inhibiting the cation exchange mechanism for acidification of urine? Subject L. G. (Table IV), who received ACTH in constant doses throughout the course of this study, was treated for six days with potassium acetate, $360 \mathrm{mEq}$. per day. During this six-day period the excretion of titratable acid ceased entirely, and the excretion of ammonia was sharply reduced. Presumably, complete inhibition of cation exchange in the renal tubules would result in a disappearance of titratable acid and ammonia from the urine and an equivalent increase in urinary sodium (13). But, 
The effect of neutral potassium phosphate on urinary electrolytes

Pt. N. C., No. 194889. White, female, 33 years. Disseminated lupus erythematosus

\begin{tabular}{|c|c|c|c|c|c|c|c|c|}
\hline \multirow[b]{2}{*}{ Day } & \multirow{2}{*}{\multicolumn{2}{|c|}{ Treatment }} & \multicolumn{6}{|c|}{ 24-Hour urinary } \\
\hline & & & $\underset{(m E q .)}{\mathrm{Na}}$ & $\underset{(m E q .)}{\mathbf{K}}$ & $\underset{(m E q .)}{\mathrm{Cl}}$ & $\underset{(m M)}{\mathbf{P}}$ & $\underset{(m \dot{E} q .)}{\text { Titr. ac. }}$ & $\begin{array}{l}\mathrm{NH}_{3} \\
(m M)\end{array}$ \\
\hline $1-6$ & $\begin{array}{l}\text { Hydrocortisone } 20 \mathrm{mg} \text {. } \\
\text { orally every } 6 \text { hours }\end{array}$ & & & & & & & \\
\hline 7 & $\begin{array}{l}\text { Hydrocortisone } 20 \mathrm{mg} \text {. } \\
\text { orally every } 6 \text { hours }\end{array}$ & & 80 & 55 & 82 & 21 & 21 & 47 \\
\hline 8 & $\begin{array}{l}\text { Hydrocortisone } 20 \mathrm{mg} \text {. } \\
\text { orally every } 6 \text { hours }\end{array}$ & & 79 & 58 & 83 & 22 & 19 & 46 \\
\hline 9 & $\begin{array}{l}\text { Hydrocortisone } 20 \mathrm{mg} \text {. } \\
\text { orally every } 6 \text { hours }\end{array}$ & & 82 & 51 & 88 & 21 & 23 & 48 \\
\hline 10 & $\begin{array}{l}\text { Hydrocortisone } 20 \mathrm{mg} \text {. } \\
\text { orally every } 6 \text { hours }\end{array}$ & & 77 & 52 & 81 & 25 & 17 & 45 \\
\hline 11 & $\begin{array}{l}\text { Hydrocortisone } 20 \mathrm{mg} \text {. } \\
\text { orally every } 6 \text { hours }\end{array}$ & $\begin{array}{l}\mathrm{KH}_{2} \mathrm{PO}_{4} 12.2 \mathrm{Gm} . \\
\mathrm{K}_{2} \mathrm{HP}_{4} 23.5 \mathrm{Gm} .\end{array}$ & 125 & 217 & 131 & 65 & 34 & 29 \\
\hline 12 & $\begin{array}{l}\text { Hydrocortisone } 20 \mathrm{mg} \text {. } \\
\text { orally every } 6 \text { hours }\end{array}$ & & 89 & 80 & 60 & 45 & 31 & 37 \\
\hline 13 & $\begin{array}{l}\text { Hydrocortisone } 20 \mathrm{mg} \text {. } \\
\text { orally every } 6 \text { hours }\end{array}$ & & 73 & 65 & 73 & 37 & 25 & 38 \\
\hline 14 & $\begin{array}{l}\text { Hydrocortisone } 20 \mathrm{mg} \text {. } \\
\text { orally every } 6 \text { hours }\end{array}$ & & 61 & 72 & 54 & 33 & 36 & 53 \\
\hline 15 & $\begin{array}{l}\text { Hydrocortisone } 20 \mathrm{mg} \text {. } \\
\text { orally every } 6 \text { hours }\end{array}$ & & 58 & 68 & 55 & 27 & 27 & 56 \\
\hline 16 & $\begin{array}{l}\text { Hydrocortisone } 20 \mathrm{mg} \text {. } \\
\text { orally every } 6 \text { hours }\end{array}$ & & 53 & 62 & 47 & 24 & 18 & 47 \\
\hline 17 & $\begin{array}{l}\text { Hydrocortisone } 20 \mathrm{mg} \text {. } \\
\text { orally every } 6 \text { hours }\end{array}$ & $\begin{array}{l}\mathrm{KH}_{2} \mathrm{PO}_{4} 12.2 \mathrm{Gm} . \\
\mathrm{K}_{2} \mathrm{HP}_{4} 23.5 \mathrm{Gm} . \\
\text { (intravenously) }\end{array}$ & 176 & 306 & 180 & 236 & 62 & 44 \\
\hline 18 & $\begin{array}{l}\text { Hydrocortisone } 20 \mathrm{mg} \text {. } \\
\text { orally every } 6 \text { hours }\end{array}$ & & 57 & 109 & 72 & 47 & 38 & 45 \\
\hline 19 & $\begin{array}{l}\text { Hydrocortisone } 20 \mathrm{mg} \text {. } \\
\text { orally every } 6 \text { hours }\end{array}$ & & 40 & 80 & 62 & 42 & 33 & 47 \\
\hline
\end{tabular}

it will be noted that in this patient the absolute magnitude of the cation exchange performed by the kidneys during pre-potassium periods was not more than $65 \mathrm{mEq}$. per day $(20 \mathrm{mEq}$. as titratable acidity plus $45 \mathrm{mEq}$. as ammonia). On the first day of potassium administration, the negative sodium balance was approximately $160 \mathrm{mEq}$. per day. Therefore, even complete inhibition of the renal tubular cation exchange mechanism for acidification of the urine cannot account for the magnitude of the natriuretic effect of potassium if it is assumed that titratable acid-ammonia excretion is a valid measure of tubular $\mathrm{H}^{+}-\mathrm{Na}^{+}$exchange.

Over-all changes in the excretion of electrolytes during administration of large amounts of potassium salts were studied in six subjects. Table I, II, and IV summarize data obtained in representative studies of three subjects. These subjects had been receiving ACTH or hydrocortisone, and, by the time the study was initiated, had already passed through the initial phase of sodium retention and were in approximate sodium equilibrium. Potassium chloride was given to one subject, potassium phosphate to the second, and potassium acetate to the third. All three subjects lost sodium initially when potassium was given, and all retained sodium after potassium was withdrawn. In all studies the $\mathrm{pH}$ of the urine increased during administration of potassium; this effect was most marked with potassium acetate and least marked with potassium phosphate. When potassium chloride or potassium acetate was given, urinary ammonia and titratable acidity became negligible, urinary phosphorus decreased sharply, and urinary carbon dioxide-plusbicarbonate increased markedly. With potassium phosphate, however, urinary titratable acidity-plusammonia actually increased.

Interestingly, in most of these experiments loss of sodium was greater than loss of chloride when either potassium acetate or potassium chloride was used. For instance, in subject L. G. administration of potassium acetate resulted in loss of both 
TABLE III

Comparison of the effects of urea and potassium salts on urinary electrolytes

Pt. R. Do., No. 130120. White, male, 31 years. Gout

\begin{tabular}{|c|c|c|c|c|c|c|c|c|}
\hline \multirow[b]{2}{*}{ Day } & \multirow[b]{2}{*}{ Treatment } & \multicolumn{7}{|c|}{ 24-Hour urinary } \\
\hline & & $\begin{array}{c}\mathrm{Na} \\
(m E q .)\end{array}$ & $\underset{(m E q .)}{\mathrm{K}}$ & $\begin{array}{c}\mathrm{Cl} \\
(m E q .)\end{array}$ & $\underset{(m M)}{\mathbf{P}}$ & $\begin{array}{l}\text { Titr. aac. } \\
(m E q .)\end{array}$ & $\underset{(m M)}{\mathrm{NH}_{\mathbf{3}}}$ & $\underset{(G m .)}{N}$ \\
\hline $1-3$ & Equilibration period & & & & & & & \\
\hline $\begin{array}{l}4 \\
5 \\
6 \\
7 \\
8\end{array}$ & $\begin{array}{l}\text { Control period } \\
\text { Control period } \\
\text { Control period } \\
\text { Control period } \\
\text { Control period }\end{array}$ & $\begin{array}{r}99 \\
98 \\
118 \\
110 \\
111\end{array}$ & $\begin{array}{l}85 \\
80 \\
73 \\
82 \\
81\end{array}$ & $\begin{array}{l}107 \\
120 \\
122 \\
124\end{array}$ & $\begin{array}{l}26 \\
24 \\
23 \\
23 \\
23\end{array}$ & 17 & 27 & \\
\hline 9 & $\mathrm{KCl}, 27 \mathrm{Gm}$. orally & 176 & 273 & 358 & 20 & 11 & 16 & \\
\hline $\begin{array}{l}10 \\
11 \\
12 \\
13 \\
14 \\
15\end{array}$ & $\begin{array}{l}\text { Control period } \\
\text { Control period } \\
\text { Control period } \\
\text { Control period } \\
\text { Control period } \\
\text { Control period }\end{array}$ & $\begin{array}{l}127 \\
117 \\
114 \\
117 \\
116 \\
120\end{array}$ & $\begin{array}{r}196 \\
117 \\
96 \\
97 \\
86 \\
77\end{array}$ & $\begin{array}{l}282 \\
151 \\
128 \\
131 \\
129 \\
125\end{array}$ & $\begin{array}{l}23 \\
33 \\
30 \\
27 \\
27 \\
26\end{array}$ & $\begin{array}{l}25 \\
33 \\
29 \\
24 \\
25\end{array}$ & $\begin{array}{l}22 \\
26 \\
25 \\
22 \\
22\end{array}$ & \\
\hline 16 & $\mathrm{~K}$ Acetate, $36 \mathrm{Gm}$. orally & 199 & 288 & 227 & 16 & -108 & 8 & \\
\hline $\begin{array}{l}17 \\
18 \\
19 \\
20 \\
21 \\
22\end{array}$ & $\begin{array}{l}\text { Control period } \\
\text { Control period } \\
\text { Control period } \\
\text { Control period } \\
\text { Control period } \\
\text { Control period }\end{array}$ & $\begin{array}{r}89 \\
108 \\
110 \\
109 \\
105 \\
98\end{array}$ & $\begin{array}{l}150 \\
111 \\
88 \\
101 \\
101 \\
107\end{array}$ & $\begin{array}{r}74 \\
93 \\
124 \\
119 \\
125 \\
114\end{array}$ & $\begin{array}{l}26 \\
32 \\
26 \\
31 \\
29 \\
29\end{array}$ & $\begin{array}{r}-34 \\
3\end{array}$ & $\begin{array}{r}7 \\
11\end{array}$ & $\begin{array}{l}15 \\
16 \\
15 \\
17 \\
17\end{array}$ \\
\hline 23 & Urea, $85 \mathrm{Gm}$. orally & 117 & 96 & 138 & 28 & & & 48 \\
\hline $\begin{array}{l}24 \\
25\end{array}$ & $\begin{array}{l}\text { Control period } \\
\text { Control period }\end{array}$ & $\begin{array}{r}96 \\
113\end{array}$ & $\begin{array}{l}87 \\
83\end{array}$ & $\begin{array}{l}111 \\
120\end{array}$ & $\begin{array}{l}27 \\
27\end{array}$ & & & $\begin{array}{l}23 \\
20\end{array}$ \\
\hline
\end{tabular}

sodium and chloride, but the magnitude of the sodium loss was much greater than that of the chloride loss. When subject V. N. was given potassium chloride, there was a net retention of both potassium and chloride, associated with a marked loss of sodium. Potassium phosphate, however, administered intravenously to subject $\mathrm{N}$. C., resulted in loss of both sodium and chloride in approximately equal quantities.

Although the administration of potassium chloride tends to correct the hypokaliemic alkalosis of Cushing's syndrome (see Table I), the natriuretic action of potassium is not dependent upon the presence of either alkalosis or hypokaliemia. Of the present series of subjects, all of whom showed natriuretic responses to potassium, only two had hypokaliemic alkalosis (V. N. and C. K.).

The urine is only one of many body fluids whose electrolyte composition is affected by adrenal steroids. The sodium-potassium ratio of saliva, for example, may be greatly decreased during treatment with ACTH or cortisone (14). Data pre- sented in Table I show that in subject V. N., the very low salivary sodium-potassium ratio induced by ACTH was not modified by doses of potassium chloride which considerably altered the urinary electrolyte pattern. It would appear, therefore, that potassium does not overcome the effect of ACTH upon the salivary sodium-potassium ratio at a time when it does modify the effect of ACTH upon the urinary electrolyte pattern.

\section{DISCUSSION}

Potassium salts tend to reverse many of the effects of adrenal steroids upon electrolyte metabolism. It is conceivable that part of the sodium loss which follows administration of potassium salts is a result of a readjustment of the intracellular electrolyte pattern, i.e., increase in intracellular potassium and decrease in intracellular sodium. This readjustment would be most apt to occur in subjects in whom there had been a prior depletion of intracellular potassium, which could be induced by any 


\begin{tabular}{|c|c|c|c|c|c|c|c|c|}
\hline \multirow[b]{2}{*}{ Day } & \multirow[b]{2}{*}{ Treatment } & & \multicolumn{6}{|c|}{ 24-Hour urinary } \\
\hline & & & $\begin{array}{c}\mathrm{Na} \\
(m E q .)\end{array}$ & $\underset{(m E q .)}{\mathrm{K}}$ & $\begin{array}{c}\mathrm{Cl} \\
(m E q .)\end{array}$ & $\stackrel{\mathrm{P}}{\mathrm{P} M)}$ & $\begin{array}{l}\text { Titr. ac. } \\
(m E q .)\end{array}$ & $\underset{(m M)}{\mathrm{NH}_{3}}$ \\
\hline 1 & ACTH-gel 40 Int. Units & & 54 & 98 & 64 & 22 & 21 & 45 \\
\hline 2 & $\begin{array}{l}\text { 1.m. daily } \\
\text { ACTH-gel } 40 \text { Int. Units } \\
\text { i.m. daily }\end{array}$ & & 70 & 92 & 86 & 22 & 13 & 40 \\
\hline 3 & $\begin{array}{l}\text { ACTH-gel } 40 \text { Int. Units } \\
\text { i.m. daily }\end{array}$ & & 48 & 83 & 60 & 22 & 17 & 47 \\
\hline 4 & $\begin{array}{l}\text { ACTH-gel } 40 \text { Int. Units } \\
\text { i.m. daily }\end{array}$ & & 63 & 83 & 70 & 22 & 16 & 48 \\
\hline 5 & $\begin{array}{l}\text { ACTH-gel } 40 \text { Int. Units } \\
\text { i.m. daily }\end{array}$ & $\begin{array}{l}\text { KAc, } 36 \mathrm{Gm} \text {. } \\
\text { orally, daily }\end{array}$ & 220 & 353 & 122 & 11 & -307 & 10 \\
\hline 6 & $\begin{array}{l}\text { ACTH-gel } 40 \text { Int. Units } \\
\text { i.m. daily }\end{array}$ & $\begin{array}{l}\text { KAc, } 36 \mathrm{Gm} \text {. } \\
\text { orally, daily }\end{array}$ & 140 & 402 & 115 & 14 & -269 & 10 \\
\hline 7 & $\begin{array}{l}\text { ACTH-gel } 40 \text { Int. Units } \\
\text { i.m. daily }\end{array}$ & $\begin{array}{l}\text { KAc, } 36 \mathrm{Gm} \text {. } \\
\text { orally, daily }\end{array}$ & 130 & 492 & 131 & 17 & -236 & 11 \\
\hline 8 & $\begin{array}{l}\text { ACTH-gel } 40 \text { Int. Units } \\
\text { i.m. daily }\end{array}$ & KAc, $36 \mathrm{Gm}$. & 118 & 405 & 108 & 16 & -288 & 12 \\
\hline 9 & $\begin{array}{l}\text { ACTH-gel } 40 \text { Int. Units } \\
\text { i.m. daily }\end{array}$ & $\begin{array}{l}\text { KAc, } 36 \mathrm{Gm} \text {. } \\
\text { orally, daily }\end{array}$ & 136 & 446 & 84 & 21 & -323 & 13 \\
\hline 10 & $\begin{array}{l}\text { ACTH-gel } 40 \text { Int. Units } \\
\text { i.m. daily }\end{array}$ & $\begin{array}{l}\text { KAc, } 36 \mathrm{Gm} \text {. } \\
\text { orally, daily }\end{array}$ & 146 & 415 & 111 & 25 & -296 & 8 \\
\hline 11 & $\begin{array}{l}\text { ACTH-gel } 40 \text { Int. Units } \\
\text { i.m. daily }\end{array}$ & & 22 & 123 & 36 & 31 & 23 & 22 \\
\hline 12 & $\begin{array}{l}\text { ACTH-gel } 40 \text { Int. Units } \\
\text { i.m. daily }\end{array}$ & & 30 & 93 & 51 & 24 & 12 & 25 \\
\hline 13 & $\begin{array}{l}\text { ACTH-gel } 40 \text { Int. Units } \\
\text { i.m. daily }\end{array}$ & & 35 & 110 & 62 & 29 & 11 & 34 \\
\hline 14 & $\begin{array}{l}\text { ACTH-gel } 40 \text { Int. Units } \\
\text { i.m. daily }\end{array}$ & & 26 & 73 & 37 & 29 & 7 & 35 \\
\hline
\end{tabular}

of a number of factors, including corticotherapy. On the other hand, part of the sodium loss which occurs when potassium acetate or potassium chloride is administered appears to result from a direct action of potassium upon the renal tubules. Berliner, Kennedy, and Orloff (15) have postulated that such an action is in the nature of inhibition of the tubular mechanism by which $\mathrm{H}^{+}$ions are excreted in exchange for $\mathrm{Na}^{+}$ions. If it is assumed that titratable acid-ammonia excretion is a valid measure of tubular $\mathrm{H}^{+}-\mathrm{Na}^{+}$exchange, then two lines of evidence indicate that this mechanism cannot account for the entire sodium loss which follows administration of potassium. First, excretion of titratable acid and ammonia may be regarded as one means of conserving an equivalent amount of sodium. Theoretically, complete suppression of the mechanism for excreting titratable acid and ammonia should result in an equivalent increase in sodium excretion. Several of the balance studies showed, however, that the total amount of titratable acid-plus-ammonia excreted during control periods is much less than the sodium loss observed during administration of potassium. Therefore, even complete suppression of titratable acid-ammonia excretion could not account for all of the actual sodium loss. Second, excretion of titratable acid-plus-ammonia became increased when potassium phosphate was administered. Here, there was no reason to believe that the sodium conservation mechanism under question was suppressed. Nevertheless, the fact that a marked sodium loss did occur suggests that there is more involved in potassium-induced natriuresis than suppression of fixed-base conservation mechanisms. In short, to the extent that potassium does inhibit $\mathrm{H}^{+}-\mathrm{Na}^{+}$ exchange in the renal tubules one may expect a resultant natriuresis; however; potassium also induces natriuresis under conditions in which $\mathrm{H}^{+}-$ $\mathrm{Na}^{+}$exchange might be occurring at a normal or even increased rate.

On the other hand, it could be assumed that the quantity of $\mathrm{H}^{+}$ion appearing in the urine either as titratable acid or with ammonia does not actually represent the total amount of tubular $\mathrm{H}^{+}-\mathrm{Na}^{+}$ exchange but only a minor fraction thereof. This 


\section{Na ${ }^{+}$LOSS IN EXCESS OF $K^{+}$RETENTION DURING ADVINISTRATION OF $\mathrm{K}^{+}$}

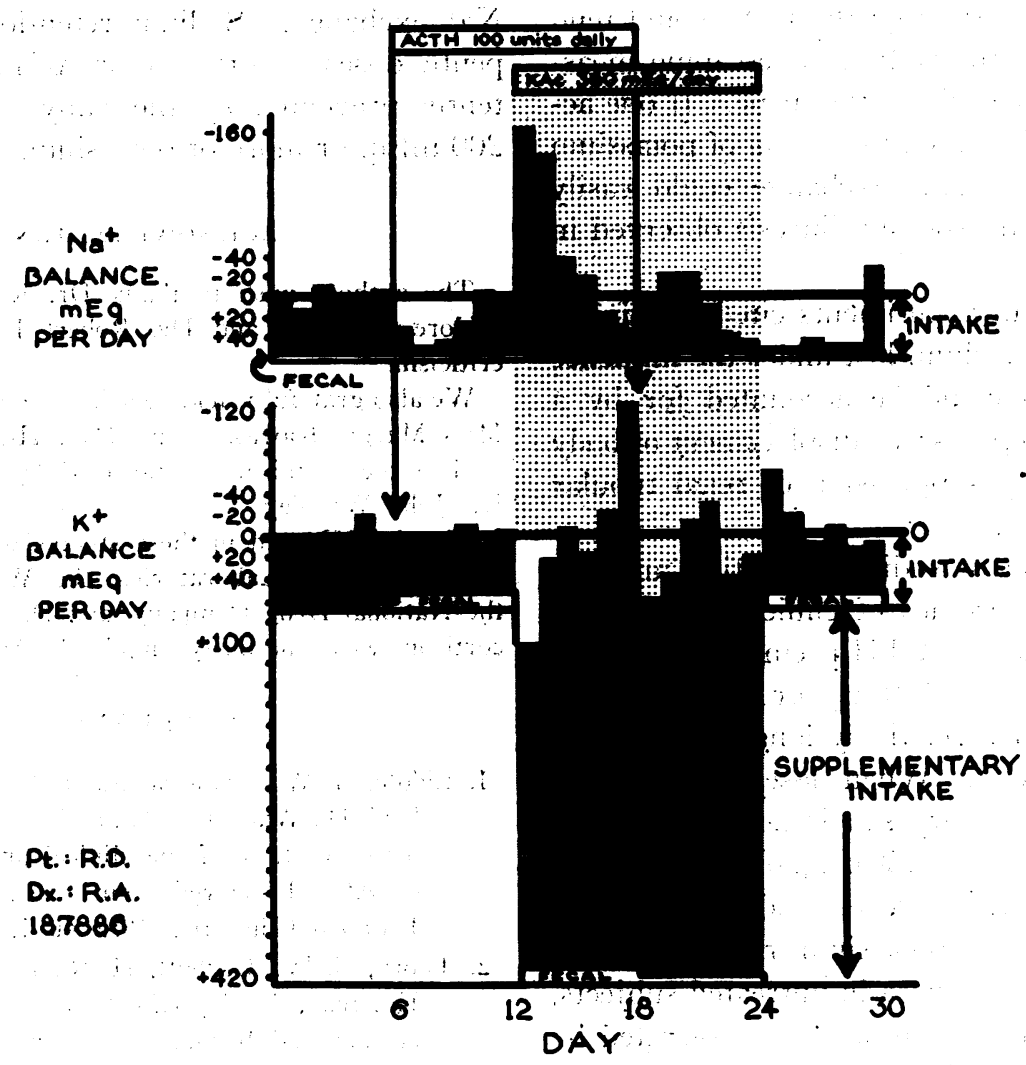

Fig. 6. Sodum Balance and Potassium Balance in Subject R. D. during Treatacent with ACTH and Potissium Acrtate

Note that the negative sodium balance (black area) is substantially greater than the positive potassium balance (white area) during the first two days of potassium administration.

TABLE $:$

Effect of, potassium phosphate ( $p H$ 7.5). ox wrimary and serwm electrolytes Pt. C. K., No. 81625, White, female, 30 years; Cushing's syndrome

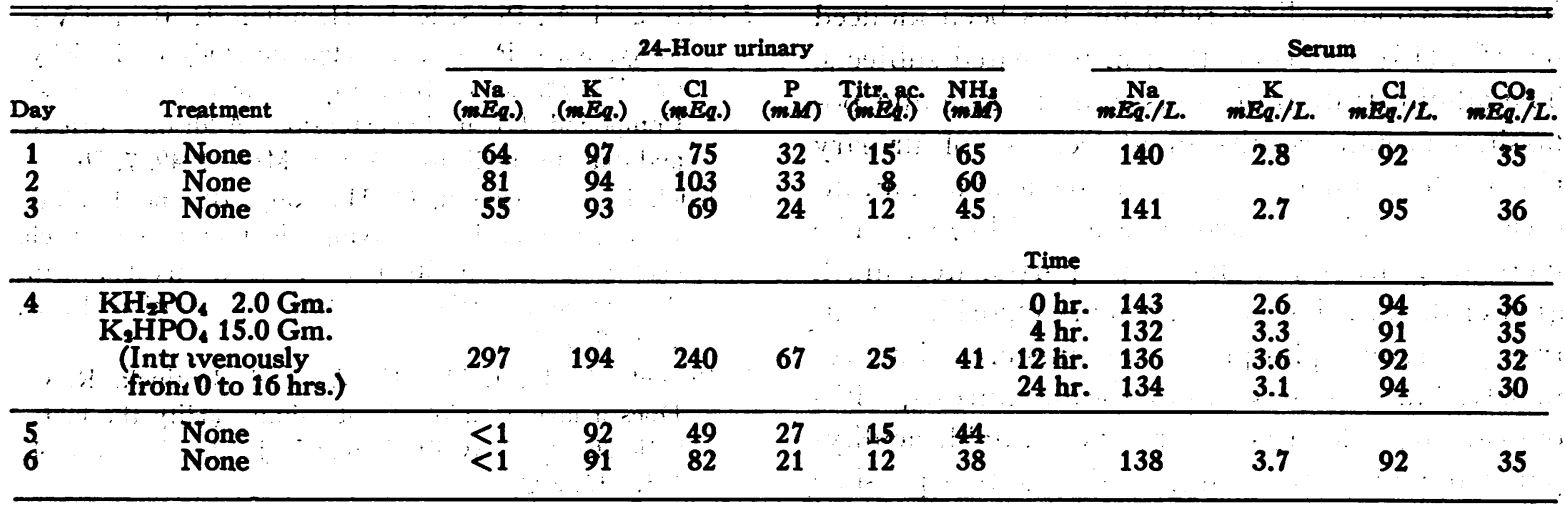


disparity might occur if, as a result of cation exchange, bicarbonate is converted to carbonic acid. The carbonic acid to some extent would become converted to $\mathrm{H}_{2} \mathrm{O}$ and $\mathrm{CO}_{2}$; the $\mathrm{CO}_{2}$ would tend to diffuse back into the body, thus escaping measurement as titratable acid in the urine. If one accepts this assumption, then the action of potassium in suppressing $\mathrm{H}^{+}-\mathrm{Na}^{+}$exchange could easily account for the entire sodium diuresis observed in these studies.

In any case, in all experiments cited in this report the amount of sodium lost under the influence of potassium salts could be accounted for by a summation of two effects : 1) displacement of body $\mathrm{Na}^{+}$by $\mathrm{K}^{+}$, plus 2) suppression of renal tubular $\mathrm{H}^{+}-\mathrm{Na}^{+}$exchange.

The complication of sodium retention and potassium depletion becomes of clinical significance only when cortisone or ACTH is employed in relatively large doses (e.g., $100 \mathrm{mg}$. or more of cortisone daily) and for a relatively long period (e.g., more than one week). When doses greater than this are given and dietary salt is not restricted, a potassium supplement of $200 \mathrm{mEq}$. or more per day is ordinarily sufficient to prevent sodium retention. Although such doses of potassium frequently cause abdominal cramps or nausea in untreated subjects, even larger amounts are usually well tolerated by subjects receiving corticotherapy. In practice it is best to divide the supplement of potassium into several small doses to be taken throughout the day.

\section{SUMMARY}

The oral administration of large doses of either potassium chloride or potassium acetate to human subjects consistently results in a diuresis of sodium. The degree of sodium diuresis is greater in subjects in whom sodium retention has been induced by ACTH or cortisone than in untreated subjects. The administration of potassium chloride and potassium acetate results in a decrease of urinary phosphate, ammonia, and titratable acid and an increase in urinary bicarbonate and chloride. The increase in urinary sodium is proportionately much greater than the increase in urinary chloride. Neutral potassium phosphate, administered intravenously, causes sodium and chloride diuresis, without causing a decrease in urinary titratable acidityplus-ammonia. It is suggested that two possible mechanisms may account for the natriuretic effect of potassium salts: 1) displacement of body $\mathrm{Na}^{+}$ by $\mathrm{K}^{+}$, and 2) suppression of renal tubular $\mathrm{H}^{+}-$ $\mathrm{Na}^{+}$exchange. Sodium retention due to therapeutic doses of cortisone or ACTH can be consistently prevented by the daily administration of $200 \mathrm{mEq}$. or more of potassium.

\section{ACKNOWLEDGMENTS}

The authors wish to thank Dr. Robert Berliner, Dr. Isidore Edelman, and Dr. Robert F. Pitts for helpful criticism.

We also gratefully acknowledge the dietetic assistance of Miss Margie Kawasaki and Mrs. Hisaye Mochizuki, as well as the technical assistance of Mr. S. J. Rehfeld and Dr. John Whitney.

The ACTH used in these studies was kindly provided by the Armour Laboratories, the Wilson Laboratories, the National Drug Company, and Dr. C. H. Li. Hydrocortisone was generously supplied by Merck and Company.

\section{REFERENCES}

1. Liddle, G. W., Giansiracusa, J. E., Childs, A. W., Island, D., Waechtler, H., and Bennett, L. L., A comparative study of the clinical and metabolic effects of ACTH derived from hogs, sheep, and cattle. J. Lab. \& Clin. Med., 1952, 40, 1.

2. Thorn, G. W., Garbutt, H. R., Hitchcock, F. A., and Hartman, F. A., Effect of cortin upon renal excretion and balance of electrolytes in the human being. Proc. Soc. Exper. Biol. \& Med., 1936, 35, 247.

3. Thorn, G. W., Howard, R. P., and Emerson, K., Jr., Treatment of Addison's disease with desoxy-corticosterone acetate, a synthetic adrenal cortical hormone (preliminary report). J. Clin. Invest., 1939, 18, 449.

4. Thorn, G. W., Engel, L. L., and Eisenberg, H., The effect of corticosterone and related compounds on the renal excretion of electrolytes. J. Exper. Med., 1938, 68, 161.

5. Perera, G. A., Pines, K. L., Hamilton, H. B., and Vislocky, K., Clinical and metabolic study of 11-dehydro-17-hydroxy-corticosterone acetate (Kendall Compound E) in hypertension, Addison's disease and diabetes mellitus. Am. J. Med., 1949, 7, 56.

6. Eliel, L. P., Pearson, O. H., Katz, B., and Kraintz, F. W., Comparison of lymphoid tumor and muscle electrolyte composition in patients treated with ACTH and cortisone acetate. Federation Proc., 1950, 9, 168.

7. Bennett, L. L., Liddle, G. W., and Bentinck, R. C., Does a large intake of potassium modify the metabolic effects of ACTH in man? J. Clin. Endocrinol., 1953, 13, 392. 
8. Schales, O., and Schales, S. S., A simple and accurate method for the determination of chloride in biological fluids. J. Biol. Chem., 1941, 140, 879.

9. Asper, S. P., Jr., Schales, O., and Schales, S. S., Importance of controlling $\mathrm{pH}$ in the Schales and Schales method of chloride determination. J. Biol. Chem., 1947, 168, 779.

10. Fiske, C. H., and Subbarow, Y., The colorimetric determination of phosphorus. J. Biol. Chem., 1925, 66, 375.

11. Folin, O., and Bell, R. D., Applications of a new reagent for the separation of ammonia. I. The colorimetric determination of ammonia in urine. J. Biol. Chem., 1917, 29, 329.
12. Henderson, L. J., and Palmer, W. W., On the several factors of acid excretion. J. Biol. Chem., 1914, 17, 305.

13. Pitts, R. F., and Alexander, R. S., The nature of the renal tubular mechanism for acidifying the urine. Am. J. Physiol., 1945, 144, 239.

14. Frawley, T. F., and Thorn, G. W., The relation of the salivary sodium-potassium ratio to adrenal cortical activity, Proc. Second Clin. ACTH Conf., Blakiston, New York, 1951, vol. 1, p. 115.

15. Berliner, R. W., Kennedy, T. J., Jr., and Orloff, J., Relationship between acidification of the urine and potassium metabolism. Effect of carbonic anhydrase inhibition on potassium excretion. Am. J. Med., 1951, 11, 274.

\section{SPECIAL NOTICE TO SUBSCRIBERS}

Post Offices will no longer forward the Journal when you move.

Please notify The Journal of Clinical Investigation, Business Office, 622 West 168th Street, New York 32, N. Y. at once when you have a change of address, and do not omit the zone number if there is one. 